\title{
THE INFLUENCE OF AUGMENTED REALITY ON RETAIL PRICING
}

\author{
Megan Daiker, Xavier University, daikerm@xavier.edu \\ Thilini Ariyachandra, Xavier University, ariyachandrat@xavier.edu \\ Mark Frolick, Xavier University, frolick@xavier.edu
}

\begin{abstract}
Virtual and or augmented reality is a new major trend that has gotten widespread attention and adoption across various industries recently. In the sales and retail industry the use of virtual reality technology in stores has the potential to reinvent the customer experience, but also to optimize pricing. By combining augmented reality store displays and price tags with customer loyalty programs, retailers have the ability to improve the customer's shopping experience. In addition this combination can ease navigation inside the stores as well as make products more affordable. With more information available and with the enhanced experience available, retail stores are better able to compete with the rise in online retail shopping.
\end{abstract}

Keywords: virtual reality, augmented reality, retail price optimizing, enhanced shopping experience

\section{INTRODUCTION}

As the single most direct influencer of the bottom line, pricing can make or break a company's financial performance. Pricing is the process used to set the price at which a product or service will be sold (Grewal et al 2011). With an one percent increase in price, stores like Walmart would see an 18 percent increase in operating profit while producers like Tyson, would see an increase of 88 percent (Mohammed, 2010, p. xiii). Many retailers operate using standardized pricing - when the price on the shelf is what everyone pays. This method of pricing neglects the customer not willing to pay that price and ignores the opportunity to charge more to the customers who value the product more.

Currently, stores like Kroger use loyalty cards to give customers who are willing to share their information a different price and often lists that price on the shelf. This can be misleading for customers and only allows for two different prices. With the use of augmented reality (AR) technology in brick and mortar store locations, retailers can combine the best aspects of in-person shopping like inspecting items with the customer-friendly aspects of online shopping such as personalized pricing, integrated store lists - showing what the customer intends to get versus what they buy, and simple navigation.

\section{PERSONALIZED PRICING AND PROFIT MAXIMIZATION}

\section{Price Elasticity}

The basis of differentiated pricing is that some customers are inelastic, where the price has little to no effect on their willingness to buy while others are elastic, where the price of an item has a large effect on their willingness to buy. Price elastic customers tend to sign up for loyalty cards and jump through hoops to get rebates, while price inelastic customers buy what they need regardless. In some markets, like life-saving medication, all customers are more inelastic and in other markets, like produce, all customers tend to be more elastic.

\section{Standardized Pricing}

With standardized pricing, which is the norm in retail environments, retailers choose a single price point and charge all (multiple) customers that price. As shown in Figure 1, the demand curve for a typical product is downward sloping, 


\section{Issues in Information Systems}

Volume 18, Issue 4, pp. 116-123, 2017

demonstrating that at each decreasing price point (where profit margins get slimmer and slimmer), more customers would be willing to purchase a good or service. In standardized pricing, sometimes called multi-customer pricing, the goal is to "find the price that is the most profitable given the trade-off between margin and products sold" (Mohammed, 2010, p.14). Not only do retailers set their prices to maximize profitability, but can use their standardized price to pursue other goals. A retailer's price point can help them penetrate the market and gain market share, it can provide value to the customer which increases their image, or it can reinforce a luxury standing as seen in Table 1.

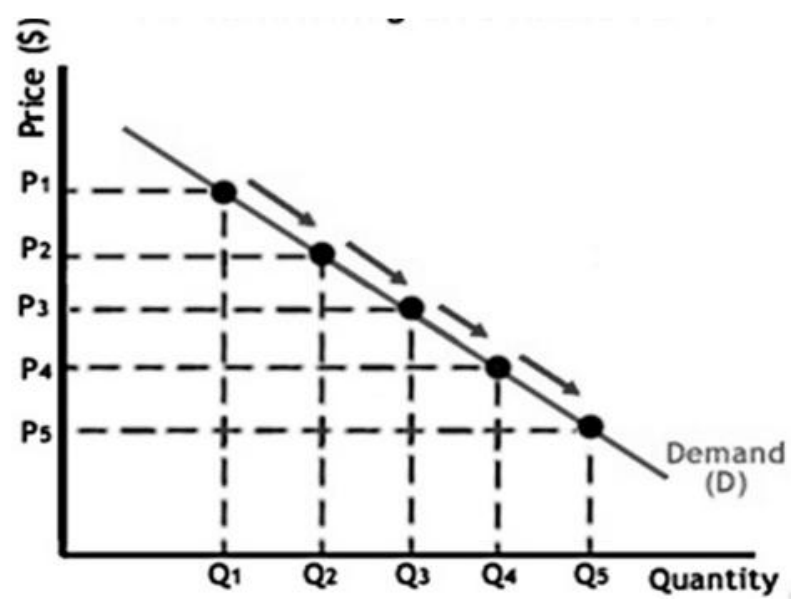

Figure 1. Movement Along the Demand Curve (Mohammed, 2010, p. 14)

Table 1. Price Strategy Setting (Baumgardner, 2017a)

\begin{tabular}{|c|c|c|c|c|}
\hline \multirow{5}{*}{$\begin{array}{l}\text { Perceived } \\
\text { Value }\end{array}$} & \multicolumn{4}{|c|}{ Price } \\
\hline & & Low & Medium & High \\
\hline & High & Superb Value & Penetration & $\begin{array}{l}\text { Premium Contact } \\
\text { (Luxury Brand) }\end{array}$ \\
\hline & Medium & Good Value & Average (Mid-Market) & Overcharging \\
\hline & Low & $\begin{array}{l}\text { Cheap Value } \\
\text { (Economy) }\end{array}$ & Skim the Cream & Rip-off Price \\
\hline
\end{tabular}

\section{RETAIL ENVIRONMENT}

As a highly competitive market, retailers are fighting with their competitors for each transaction and within that transaction, brands are fighting with their competitors for each dollar. To further complicate the matter, most stores carry private labels which are priced lower to compete with the profitable national brands with massive marketing budgets. Retailers are known for using promotions to drive sales like coupons, deals, and loyalty cards.

\section{Retail Business}

Retailers, by definition, are businesses who sell goods in relatively small quantities direct to consumers. They purchase most of their goods from wholesalers or distributors, thus are labeled $\mathrm{B} 2 \mathrm{~B} 2 \mathrm{C}$ or business-to-business-to-consumer companies. Their stores can be virtual, like Amazon, or brick and mortar like Walmart, Target, or Costco. The nature of their business, buying and reselling at a markup, means that their profit margins are much smaller than a direct-toconsumer producer because the retailer must share the profit with the manufacturer and distributor. Retailers typically employ a buyer who purchases from the distributor or manufacturer, stocking the shelves. The manufacturer suggests a price, the Manufacturer Suggested Retail Price or MSRP, to establish the list price to be paid by the retailer (Table 2). However, the manufacturer has no power over the retailer's selling price. Instead, manufacturers can set the list 


\section{Issues in Information Systems}

Volume 18, Issue 4, pp. 116-123, 2017

price higher or lower than the retailer's selling price by attaching the MSRP onto the product's packaging. Manufacturers can allocate trade funds to support promotions or get more favorable locations, but the laws surrounding these allocations are treacherous. Large manufacturers like Unilever or $P \& G$ have some power over retailers which they use to get better shelf space/location and encourage them to follow their price suggestions, but many small manufacturers struggle to sell to retailers who demand very low prices (Baumgardner, 2017b).

Table 2. Retail Price Environment (Baumgardner, 2017b)

\begin{tabular}{|l|}
\hline Retail Price \\
\hline -Manufacturer List Price \\
\hline -Transport costs \\
\hline -Workroom Costs \\
\hline +Cash Discount \\
\hline 'Front' Gross Margin \\
\hline $\begin{array}{l}\text { +Trade Funds from Suppliers } \\
\text { (complicates B2B2C pricing) }\end{array}$ \\
\hline $\begin{array}{l}\text { Back Margin (Drivers buyers' } \\
\text { decisions) }\end{array}$ \\
\hline
\end{tabular}

\begin{tabular}{|l|l|l|}
\hline Basic Category Roles & $\begin{array}{l}\text { Drivers for Development of } \\
\text { Strategies }\end{array}$ & $\begin{array}{l}\text { Strategies for } \\
\text { Growth/Profitability }\end{array}$ \\
\hline Destination (milk) & Total \# of shopping trips & Traffic Building \\
\hline Routine (toilet paper) & $\%$ trips that contain category & Transaction building \\
\hline $\begin{array}{l}\text { Occasional (Easter } \\
\text { Baskets) }\end{array}$ & $\begin{array}{l}\text { Value transaction of market } \\
\text { basket }\end{array}$ & Profit Contribution \\
\hline $\begin{array}{l}\text { Convenience (One stop } \\
\text { shopping) }\end{array}$ & Gross Margin & Cash Generation \\
\cline { 2 - 3 } & Actual Profit & Excitement Creation \\
\cline { 2 - 2 } & Image Enhancement \\
& & Turf Defending \\
\cline { 2 - 2 } & &
\end{tabular}

Retailers are losing more and more sales to online sellers in recent years. Companies like Amazon offer almost unbeatable convenience and are perceived to have low prices. One out of every six discretionary dollars is being spent online (Fulgoni \& Lipsman, 2016) and retailers are having trouble creating successful multi-channel offerings. The struggle for these companies is fully aligning their inventory and information systems to create a seamless omnichannel offering (Tritsch, 2014). Not only can customers go to an electronics store, test a product, then purchase from a competitor before leaving the store, but they can find more information than ever about each product and no longer rely on information given to them by the retailer or manufacturer. The growth in mobile use is shown in Figure 2 with an increase of 49 percent and while brick and mortar sales are still a huge majority, they need to be prepared to adapt to a changing customer base. 


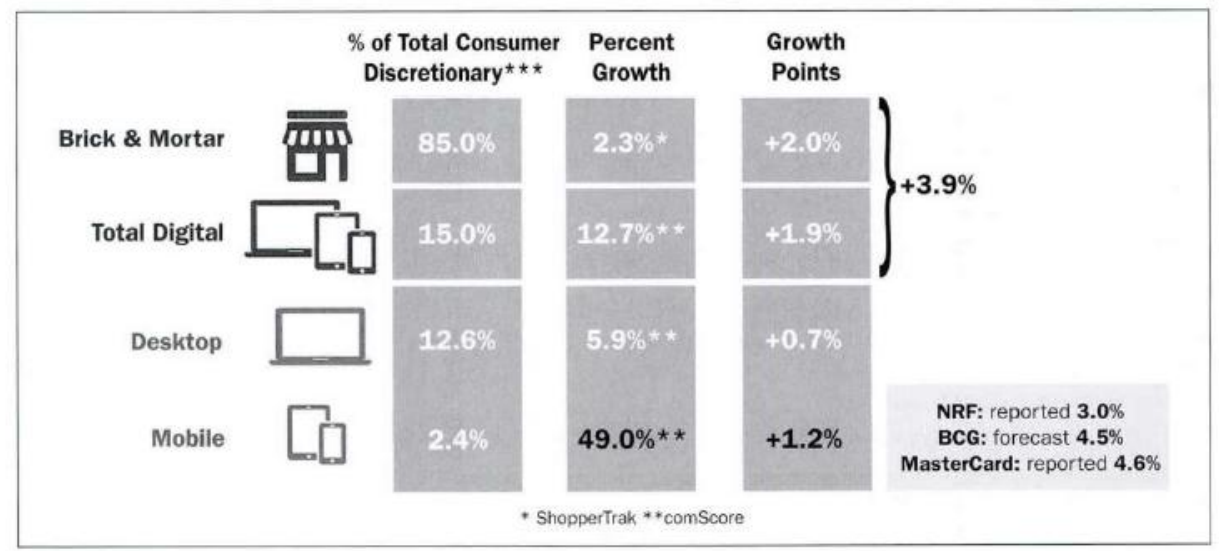

Figure 2. Growth in Online Sales vs. Brick \& Mortar

\section{Loyalty Cards}

Loyalty programs allow stores to track their customers with more accuracy than before and provide them with applicable discounts in return for this information. Throughout history, loyalty programs have been as simple as a punch card for a free drink and as complicated as Kroger's Kroger Plus Card. These programs give sellers " "better customers,'... more loyal to their suppliers and often give them a greater share of their business" and these customers report having better suppliers (Dowling, 1997, p. 72). The objectives of these win-win programs are maintaining sales levels, margins, and profits, increase the loyalty and potential value of existing customers, encourage customers to try new products, differentiate from competitors, preempt a new competitor's market entrance, and preempting an existing competitor from offering a similar loyalty program (Dowling, 1997, p.73).

Modern loyalty programs allow stores to serve their customers better and customers see the benefit in the points and coupons they earn. According to market research done by Bond Brand Loyalty, 70 percent of consumers are influenced by the opportunity to maximize rewards points earned and one third said they "wouldn't show as much dedication to their favorite brands if not for their loyalty programs" (Renfrow, 2015). With Amazon and Kroger topping the customer satisfaction charts, the top drivers of loyalty program satisfaction were ease of use, amount of dollars accumulated, and the appeal of the rewards. Contrary to popular belief, however, the survey did not show that mobile applications were the best direction for retailers to go as only 12 percent of shopper said they had downloaded a store's rewards app (Renfrow, 2015).

\section{AUGMENTED REALITY IN RETAIL}

Technology speculators have guessed that augmented reality or AR will have a massive effect on retail. AR puts artificial objects into the actual environment a person is in (Jackson, 2015). Consumers utilizing this technology in store along with store software would allow them to see their store list virtually while they shop, see their coupons and prices tied to their loyalty membership on the shelf, have live directions to guide them to specific items in the store, and have a more personalized and interactive experience with the store location. Its ability to combine the convenience of online shopping and the tactile advantages of brick and mortar stores has attracted investments of dozens of companies who have started to perfect the technology.

Lowe's, for example, is piloting a program called "Holoroom" which "helps nudge people over the biggest hurdle when it comes to a room refresh: imagining what those changes will look like in real life" (Li, 2016). They are using Google's Cardboard Viewer, distributed through free vending machines on site to allow users to take the design home and see a new countertop, for example, would change how the entire room looks. Other sellers, like Samsung, are using virtual and augmented reality in other ways. Samsung gave customers in some locations the opportunity to try out their Oculus headset to 'experience' a cruise and included a sweepstakes, giving them the chance to experience it 


\section{Issues in Information Systems}

Volume 18, Issue 4, pp. 116-123, 2017

in person. At their New York flagship location, the space is designed to host events to give people experiences (with their Samsung products) (Heller, 2016).

A focus on experience is not new to retail, which has been able to charge customers more for the same products by nurturing a comfortable, home-y environment, or a luxurious and exclusive image. Miya Knights, global retail technology director at Planet Retail states "As a showroom, fulfillment hub and center for service excellence, the physical store still reigns supreme when it comes to delivering truly instant retail therapy. The fact that the in-store customer experience topped our poll suggests retailers are starting to capitalize on this" (PR, 2017). Researchers say that virtual reality will "offer merchants a bevy of impressive new ways to share their brand's story with customers" (Bianchi, 2016). The current issue with many AR applications in retail is that each customer would need their own gear, or headset. For now, this is very costly, but both the size of the headsets and their price are quickly dwindling.

\section{RETAIL PRICING}

To drive customer sales, retailers can use dozens of distinct strategies. They can sell loss leaders to get customers in the store, they can offer free Wi-Fi, they can buy prime lots to put their stores in convenient places, and they can have unique products that only they carry. Many customers are willing to shop in stores with less choices and spend more money on each product based on other benefits they receive. Customers do not, however pay directly for the benefits, but place their own value on them and are willing to pay that amount (Nagle, 2005). The most direct effect on profit, however, comes from collecting as much value as they can from each customer through strategic pricing. In retail specifically, price setters use information collected about consumers to drive their choices.

Decision makers put products into categories like destination and convenience to help them understand where to price them. For example, a destination product like milk must be priced competitively because a sale on milk at Kroger is more likely to bring in a budget-friendly shopper than a sale on staples. If a product is in the convenience category, they know that customers are less likely to be price sensitive and can charge more for a bottle of coke at a gas station than they could in a six-pack at Walmart. To further improve their choice of strategy, a retailer will also look at other factors like the percentage of trips that include an item from that category and the profit they make from it. With this information, they can make better decisions on how to use that product, whether it is to simply get people into the store, to get them to buy a larger variety of items on their trip, or to help keep customers away from a competitor.

\section{AUGMENTED REALITY AND PRICING}

\section{Opportunities}

The use of AR technology has massive potential, in the maximization of retail profits, by optimizing customer identification. Retailers need to create a platform that is fully functional and can help customers with a variety of tasks using augmented and virtual reality. This platform would allow users to see, enter and keep their store lists, navigate the store, and view individual prices on items based on their loyalty data. In the store, users without VR gear or loyalty memberships would see the highest price the store offers for that item. Some grocery chains are reluctant to adopt a loyalty program since their rewards are not considerable enough to entice shoppers and "cannot offer better rewards, according to conventional wisdom, because of their razor-thin margins fueled by extremely competitive market conditions" (HBS Working Knowledge, 2014). This problem could be solved by using AR systems as customers would only have access to and use promotions that would have a real, measurable effect on their shopping.

The collection of data from entering a store list, coupled with loyalty program data, retailers can put customers into different groups based on their price elasticities to certain products. For example, a customer who often comes to the store and buys weekly groceries, baby food, and diapers is like to be more sensitive to the price of these things. A retailer is more likely to influence their decision of where to shop by having a sale on diapers than they could with a sale on expensive wine. This retailer could put this customer into a group called 'Caregivers' and would show them the lowest price on diapers via their virtual reality headset. On the contrary, if a customer stops in twice a month and picks up just diapers and beer, they would be put into an inelastic group. Even if they are also a rewards member, they 
would be shown a higher price on diapers because they are not likely to know the price is higher and might just want to get the product and get out. The AR system allows the individual customer to have access to an easy, individual price that is most attractive to them when it's important to them. By segmenting shoppers even further than loyalty/not, the retailer can capture the most value from each purchase.

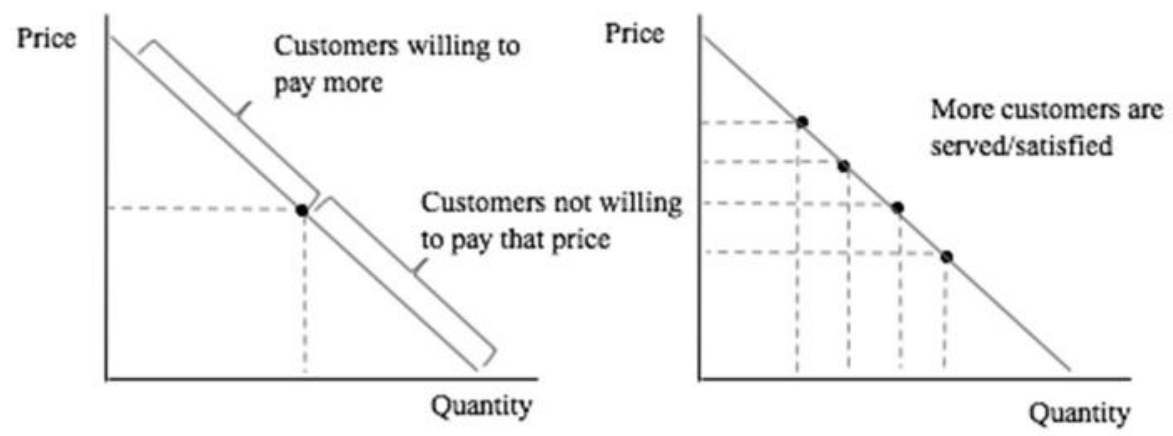

Figure 3. Opportunity of Personalized Pricing

The demand curves shown in Figure 3, demonstrate the opportunity of personalized pricing. The scenario on the left of Figure 3, shows standardized pricing, where every customer who is willing pays a single price. Customers not willing to pay that much are not served and potential profit is lost as customers willing to pay more are charged a lower price. With the use of virtual reality to allow simple, personalized pricing in brick and mortar retail locations as shown on the right of Figure 3, more prices can be offered to customers based on their elasticity and willingness to pay. A customer happy to pay $\$ 5$ for a product is charged more than a customer who refuses to pay more than $\$ 3.50$. Perfectly executed, "every consumer should be content to pay what he/she is willing to pay; no consumer would be presented with a price too high" (Obermiller, Arnesen \& Cohen, 2012). With some customers paying higher prices and others paying lower prices, the retailer can cater not only the experience, but the pricing structure to suit each customer.

\section{Risks}

Personalized pricing using virtual reality headsets could have risks. First, the implementation of a virtual reality system could be costlier than the potential profit growth of the personalized pricing system, especially if implemented too early in the technology's life. It could also have negative effects in customer perception. If a customer sees someone else's price, they would likely feel cheated by the store. Even though the store would not be.

Baired (2017) provides a series of questions that describe the different legal and policy issues that could emerge from customized pricing:

"Pricing can create a lot of challenges about policy. What happens if the price changes from when you put it in the online cart to when you start processing the transaction? If you're a store-based retailer, how do you manage fluctuating prices online compared to static prices at the shelf? What happens if you agree to price match, but then discover that the competitive price increased before the shopper made it to the checkout? Or that your own online store offers a lower price than the physical store?increasing the baseline price, a customer who is accustomed to discounts might not think the system was fair." (Baired 2017)

Finally, charging different customers different prices might have legal implications if not closely tied to a rewards program.

\section{CONCLUSION}

Virtual and augmented reality is the next big technology trend and its implications spread all the way from gaming, to medicine, to shopping. The use of virtual reality technology in stores has the potential to reinvent the customer 


\section{Issues in Information Systems}

Volume 18, Issue 4, pp. 116-123, 2017

experience, but also to optimize pricing. By combining AR store displays and price tags with a loyalty program, the retailer can improve customer experience, make more products affordable to them, and even make their stores easier to navigate. With more ease of use in the store, customers may even be willing to pay more to shop at stores with the system installed. As online vendors take market share away from traditional brick and mortar retailers, the increase in ease of use might be enough to bring some of the shoppers away from their computers and back into physical stores.

\section{REFERENCES}

Baired, J. (2017, April 18) Dynamic Pricing: When Should Retailers Bother? Retrieved February 23, 2017, from https://www.forbes.com/sites/nikkibaird/2017/04/18/dynamic-pricing-when-should-retailersbother/\#52b2e73721be

Baumgardner, E. (2017, January 24). Price Structures and Tactics. Lecture presented in Xavier University, Cincinnati, $\mathrm{OH}$.

Baumgardner, E. (2017, February 7). Retail Price Environment. Lecture presented in Xavier University, Cincinnati, $\mathrm{OH}$.

Bianchi, J. (2016, July 6). How Virtual Reality Helps Retailers Lure in Customers (And Keep Them) - Shopify. Retrieved February 23, 2017, from https://www.shopify.com/retail/how-virtual-reality-helps-retailers-lurein-customers-and-keep-them

Dowling, G., \& Uncles, M. (1997). Do Customer Loyalty Programs Really Work? Sloan Management Review, $38(4), 71-82$.

Fulgoni, G., \& Lipsman, A. (2016). The Future of Retail is Mobile. Journal of Advertising Research. doi: 10.2501/JAR-2016-041

Grewal, D., Ailawadi, K. L., Gauri, D., Hall, K., Kopalle, P., \& Robertson, J. R. (2011). Innovations in retail pricing and promotions. Journal of Retailing, 87, S43-S52.

HBS Working Knowledge. (2014, February 24). Six Myths About Customer Loyalty Programs. Retrieved April 10, 2017, from https://www.forbes.com/sites/hbsworkingknowledge/2014/02/24/six-myths-about-customerloyalty-programs/\#5d27167947cc

Heller, L. (2016). Virtual Reality Will Save Retail. Forbes. Retrieved April 10, 2017, from https://www.forbes.com/sites/lauraheller/2016/02/22/virtual-reality-will-save-retail/print/

Jackson, B PhD on June 3, 2015, B. (2017, January 11). What is Virtual Reality? VR Definition and Examples | Marxent. Retrieved April 13, 2017, from http://www.marxentlabs.com/what-is-virtual-reality-definitionand-examples/

Li, S. (2016, April 11). How retail stores are using virtual reality to make shopping more fun. Los Angeles Times. Retrieved April 9, 2017.

Mohammed, R. (2010). The 1\% windfall: how successful companies use price to profit and grow. New York: Harper Collins.

Nagle, T. (2005). Pricing the Differential. Marketing Management, 25-32.

Obermiller, C., Arnesen, D., \& Cohen, M. (2012). Customized Pricing: Win-win or End Run? Drake Management Review, 1(2). Retrieved April 10, 2017.

PR, N. (2017, March 2). New Survey Reveals Key Retail Technology Trends. PR Newswire US. 


\section{Issues in Information Systems}

Volume 18, Issue 4, pp. 116-123, 2017

Renfrow, J. (2015). Amazon, Kroger offer most satisfying loyalty programs. Fierce Retail. Retrieved April 10, 2017. Tritsch, R. (2014). Trends \& Technologies In Retail. Checkout, 40(10), 58. 